\title{
PENGARUH MOTIVASI DAN BERPIKIR KRITIS PADA PEMBELAJARAN ONLINE DALAM PERSPEKTIF SISWA SMK
}

\section{THE EFFECT OF MOTIVATION AND CRITICAL THINKING ON ONLINE LEARNING IN THE PERSPECTIVE OF VOCATIONAL SCHOOL STUDENTS}

\author{
Yunvita Noryanti', Henita Rahmayanti', Ilmi Zajuli Ichsan ${ }^{3}$ \\ ${ }^{1,2,3}$ Universitas Negeri Jakarta, Jl. Rawamangun Muka Raya No. 11, DKI Jakarta, 13220, \\ Indonesia \\ 1yuwita.novyanti@gmail.com
}

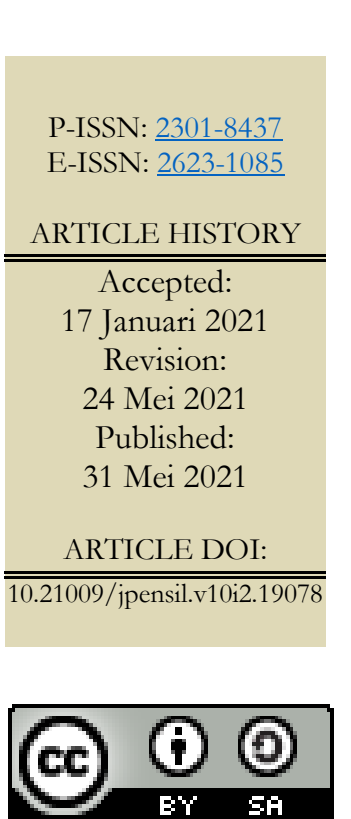

Jurnal Pensil : Pendidikan Teknik Sipil is licensed under a Creative Commons Attribution-ShareAlike 4.0 International License (CC BY-SA 4.0).

\begin{abstract}
Abstrak
Ancaman kesehatan dunia saat ini adalah penyakit yang berasal dari virus yang menyerang saluran pernapasan yang disebut Coronavirus Disease 2019 (Covid-19). Karena Covid-19, seluruh sistem kehidupan telah berubah secara besar-besaran di semua aspek kehidupan. Pemerintah di berbagai negara telah menerapkan lockdown. Salah satu dampak lockdown khususnya dalam dunia pendidikan Indonesia adalah pembelajaran dilakukan di rumah secara online. Karena pembelajaran dilakukan secara online maka perlu mendorong siswa untuk merangsang semangat belajar salah satunya dengan meningkatkan motivasi belajar, yang kemudian dengan motivasi tersebut siswa mampu berpikir kritis untuk memperoleh prestasi yang diinginkan. Penelitian ini bertujuan untuk mendeskripsikan motivasi dan berpikir kritis selama pembelajaran online. Metode deskriptif digunakan dalam penelitian ini dan menggunakan google form untuk mengumpulkan data survei dari beberapa SMK di beberapa kota di Indonesia. Penelitian ini dilakukan selama bulan November 2020. Hasil penelitian menunjukkan bahwa tidak terdapat pengaruh yang signifikan antara motivasi dan berpikir kritis terhadap hasil belajar online pada SMK.
\end{abstract}

Kata kunci: Covid-19, Motivasi, Berpikir Kritis, Pembelajaran Online, Siswa SMK

Abstract
The current world health threat is a disease originating from a virus that attacks the
respiratory tract, and recently it has been called Coronavirus Disease 2019 (Covid-
19). Because of Covid-19, the entire system of life has changed massively in all
aspects of life. Governments in various countries have implemented lockdowns. One
of the effects of the lockdown, especially in Indonesian education, is that learning is
carried out at home online. Because learning is carried out online, it is necessary to
encourage students to stimulate the enthusiasm for learning, one of which is by
increasing learning motivation, which is then with that motivation students are able
to think critically to obtain the desired achievement. This study aims to describe


motivation and critical thinking during online learning. Descriptive method is used in this research and google form is used for survey data collection from several vocational high schools in several cities in Indonesia. This research was conducted during November 2020. The results showed that there was no significant influence between motivation and critical thinking on online learning outcomes in vocational high school students.

Keywords: Covid-19, Motivation, Critical Thinking, Online Learning, Vocational School Students

\section{Pendahuluan}

Ancaman kesehatan dunia saat ini adalah adanya penyakit yang berasal dari virus yang menyerang pernapasan, dan belakangan ini disebut Penyakit Coronavirus 2019 (Covid-19). Covid-19 diakui pada Desember 2019. Hingga saat ini Covid-19 ini masih ada di seluruh dunia, termasuk di Indonesia. Dengan meningginya angka kematian terkait kasus tersebut, sehingga muncul kebijakan pemerintah di berbagai negara termasuk Indonesia dengan menerapkan lockdown atau karantina. Selain lockdown sendiri pemerintah Indonesia mengantisipasi pandemi ini dengan kebijakan PSBB (Pembatasan Sosial Berskala Besar). Jakarta dengan kasus Covid-19 terbanyak mengharuskan masyarakatnya untuk lockdown, dan menerapkan PSBB. Dengan adanya kebijakan tersebut berdampak pada seluruh aspek kehidupan. Khususnya aspek ekonomi dan pendidikan. Adanya PSBB dan lockdown ini mengakibatkan angkutan yang berlalu lalang terbatas serta proses KBM (Kegiatan Belajar Mengajar) yang semula dilakukan secara langsung di sekolah menjadi dirumah masing-masing siswa secara online.

Pembelajaran secara online ini dilakukan bukan hanya di Jakarta namun dibeberapa kota lainnya di Indonesia seperti Bandung, Sukabumi, Tanggerang dan kotakota lainnya di Indonesia. Untuk kegiatan belajar mengajar secara online ini dilakukan oleh seluruh jenjang pendidikan. Sekolah Menengah Kejuruan (SMK) memiliki peranan yang sangat penting untuk mempersiapkan tenaga kerja yang terampil dan cekatan serta memiliki tuntutan untuk dapat selalu mengikuti perkembangan permintaan pasar (Wibowo, 2016). Sekolah Menengah Kejuruan mempelajari banyak mata pelajaran produktif dengan perbandingan teori dan lebih banyak praktikum. Dilemanya pada saat pandemi Covid- 19 ini untuk kompetensi dasar yang seharusya dipraktikan menjadi tidak maksimal atau bahkan dihilangkan.

Pandemi Covid-19 di Indonesia terjadi saat Indonesia sudah memasuki revolusi industri 4.0 dimana ditandai dengan komputasi data dan kecerdasan buatan (artificial intelligence) serta teknologi virtualisasi yang sudah baik. Adanya perkembangan teknologi saat ini berdampak dalam perkembangan pembelajaran online bagi siswa. Hal ini dapat diperoleh siswa sesuai dengan layanan online yang tersedia yang dapat disesuaikan dengan kebutuhan siswa seperti menggunakan aplikasi seperti room, webex, google meet, microsoft team, skype dan sebagainya (Alhawiti et al., 2017). Maka dengan adanya pembelajaran online ini aplikasi yang mendukung dalam pembelajaran pun sudah cukup lengkap karena hampir semua menggunakan aplikasi dan komputasi data. Selain itu menurut (Enriquez, 2014; Sicat, 2015; Iftakhar, 2016) dalam (Sadikin \& Hamidah, 2020) mengemukakan bahwa macam- macam media yang dapat dipakai untuk menunjang pembelajaran online seperti Google Classroom, Wekiddo, Edmodo, LMS, Schoology dan 
sebagainya. Pembelajaran online juga biasanya dilaksanakan secara langsung melalui media lain yang bisa live seperti Instagram, Youtube dan Facebook (Kumar \& Nanda, 2019).

Pelaksanaan pembelajaran secara online berlangsung pada skala yang belum pernah terjadi sebelumnya. Di pedalaman hutan dan desa yang sangat terpencil serta memiliki banyak penduduk usia sekolah menjadi serba kebingungan dengan kondisi yang terjadi, karena infrastruktur disana sangat terbatas (Syah, 2020). Namun saat ini ada juga siswa yang pada saat pemakaian smartphone dan laptop pada pembelajaran online dapat meningkatkan hasil belajarnya (Anggrawan, 2019). Penelitian terdahulu sudah banyak dilakukan terkait motivasi belajar dan berpikir kritis saat pandemi Covid-19 dan Indonesia sudah memasuki revolusi industri 4.0. Beberapa penelitian menunjukkan bahwa terdapat peningkatan motivasi belajar menggunakan google classroom saat pandemi covid-19 terhadap hasil belajar (Umairah, 2020). Motivasi belajar pada siswa yang mengikuti pembelajaran online di tengah situasi pandemi virus Covid-19 semakin menurun (Cahyani et al., 2020). Selain itu penelitian lain menyebutkan adanya pengaruh yang banyak tentang metode pembelajaran secara online pada motivasi belajar khususnya untuk mahasiswa (Nursalam, 2016 \& Fallis, 2013). Selain itu penelitian akan industry 4.0 menjawab sebuah pertanyaan akan pentingnya literasi baru, seperti membaca ebook atau menonton dan mendengarkan pembelajaran atau informasi yang menambah ilmu pengetahuan dari internet (Ibda, 2018).

Menurut (Hennesey, 1999) dalam (Polat \& Aydin, 2020) mengemukakan bahwa berpikir kritis ialah salah satu keahlian abad ke- 21 yang diperlukan oleh bermacam sektor. Dimulai proses pendidikan dan pelatihan hingga pekerjaan. Kemampuan berpikir kritis mengizinkan orang buat menekuni pendapatnya sendiri, menunjukkan konsistensi dan menghasilkan generalisasi dengan mengevaluasi kebenaran yang berbeda dan menafsirkan pengalaman yang dirasakan secara rasional. Oleh sebab itu, keahlian berpikir kritis merupakan perlengkapan bernilai buat menciptakan penilaian yang pas tentang suasana yang dialami. Lebih Lanjut menurut (Stanovich \& West, 2000) dalam ( $\mathrm{Ku}$ et al., 2019). Berpikir kritis merupakan proses metakognitif, terdiri dari sebagian keahlian, yang apabila digunakan spemikirannya dapat menghasilkan kesimpulan logis untuk pemecahan sebuah kasus. (Quinn et al., 2020)

Faktor awal pengembangan berpikir kritis merupakan perancah yang merupakan suatu konsep pembelajaran filsafat konstruktivisme. Pemikiran kritis, biasa dituturkan bagaikan pemikiran rasional logis, mempunyai tempat kelahirannya dalam filsafat. Dengan demikian, berpikir kritis ialah kemampuan kognitif yang bisa dianjurkan serta dipelajari. Diasumsikan jika pemikir kritis menciptakan keputusan yang lebih baik, pemecah permasalahan yang lebih baik, serta secara handal lebih kompeten (Averkieva et al., 2015)

Berpikir kritis biasanya mempunyai tiga komponen diantarnya proses terampil membuat konsep, mempraktikkan, menganalisis, mensintesis pengetahuan; tata cara mengamati, merefleksikan, menalar, atau berbicara; serta membuat akuisisi pengetahuan (Averkieva et al., 2015). Berpikir kritis juga merupakan seni menganalisis berpikir dengan tujuan untuk memperbaiki (Harasym et al., 2008). The American Association of Colleges of Nursing (2008) dalam (Seibert, 2020), mendefinisikan berpikir kritis merupakan sebagian dari proses pertanyaan, analisis, sintesis, interpretasi, inferensi, penalaran induktif dan deduktif, intuisi, aplikasi, dan kreativitas.

Motivasi membuat belajar sangat berfungsi untuk siswa serta pengajar yaitu guru. Pendidikan mandiri, memusatkan pendidikan yang awalnya bermula dari pemikiran serta sikap yang diperoleh oleh diri sendiri lalu oleh siswa secara sistematis ditunjukan pada target kompetensi inti serta 
kompetensi dasar (Sjukur, 2013). Menurut (Slavin, 2009) dalam (Sjukur, 2013) Motivasi intrinsik siswa pada dasarnya berasal dari sekolah dasar sampai sekolah menengah. Sekolah mempraktikkan bermacam insentif ekstrinsik seperti pujian, nilai, penghargaan, hingga hadiah. Menurut (Augusta, 2017) dalam (Nursalam, 2016 \& Fallis, 2013) motivasi belajar bisa dipengaruhi oleh pemakaian smartphone yang digunakan untuk mengakses pengetahuan baru dengan lebih kilat, pemakaian smartphone sebab siswa lebih banyak berkomunikasi lewat sosial media, bermain permainan, dan juga mendengarkan lagu sampai tertidur, perihal tersebut hendak pengaruhi motivasi belajar siswa yang berakibat pada menurunnya prestasi belajar. Para psikolog serta guru yakin motivasi merupakan kunci utama untuk meningkatkan kinerja. Namun adakalanya motivasi pada siswa itu menurun. Hal ini menjadi tantangan tersendiri bagi para guru untuk terus memotivasi siswanya. Riset dalam sebagian dekade terakhir meyakinkan kedudukan motivasi sangat berarti dalam tingkatkan keinginan siswa untuk belajar (Malekian et al., 2013).

Seperti yang disoroti oleh Ryan dan Deci (2000) dan Elliott dan Dweck (1988), motivasi intrinsik dan motivasi karir dapat secara universal menjelaskan bagaimana keyakinan motivasi diri seseorang mengarahkan perilaku berorientasi pada tujuan mereka. Orang merasa termotivasi secara intrinsik ketika mereka tertarik dan menikmati suatu kegiatan belajar dan merasa puas olehnya. Paradigma pembelajaran online sudah mengganti pengajaran yang awalnya berorientasi pada guru lebih berorientasi pada siswa. Pendidikan dimasa digital inimerupakan pendidikan yang efisien dengan memakai teknologi. Terlebih dikala Covid-19 yang lagi dirasakan dikala ini. Pembelajaran secara online ini wajib dikembangkan oleh guru serta siswa sehingga siswa senantiasa belajar dan menemukan teknologi terbarukan (Pujiasih, 2020).
Guru dapat menyajikan bahan ajar kepada siswanya secara sistematis yaitu dengan memanfaatkan media yang bisa menarik kepedulian siswa. Penyampaian materinya pun diusahakan tidak terlalu lama agar konsentrasi siswa untuk mencermati uraian jadi bermakna. Aplikasi yang digunakan dalam pembelajaran secara online diantaranya zoom, google class room, googlr mrrt, webex, Microsoft team dan sebagainya. Untuk membuat video pembelajaran dengan uraian pendek dapat dibagikan meleui WhatsApp, youtube serta rekaman video pembelajaran ini dapat digunakan secara berulang- ulang. Dalam perihal ini guru dituntut dapat memakai teknologi untuk digunakan dalam pendidikan serta membutuhkan smartphone. (Pujiasih, 2020).

Pembelajaran online menghubungkan siswa dengan sumber yang akan dipelajarinya (database, ahli/ instruktur, bibliotek) yang secara terpisah namun dapat terhubung ataupun bekerjasama Pembelajaran online merupakan wujud pendidikan jarak jauh yang menggunakan telekomunikasi serta data, seperti internet. Pembelajaran yang tepat guna adalah pembelajaran yang mampu memakai teknologi informasi dan komunikasi secara optimal dalam proses pembelajarannya sebagai alat bantu. Salah satu pemanfaatan teknologi informasi dan komunikasi dalam pembelajaran secara online adalah dengan memanfaatkan elektronik learning sebagai pelengkap dalam pembelajaran online (Sadikin \& Hamidah, 2020)(Hanum, 2013). Namun dalam kenyataannya penggunaan strategi pembelajaran online yang dilakukan sampai saat ini belum berjalan optimal (Ichsan et al., 2020)

Permasalahan yang muncul adalah pada pembelajaran online, siswa Sekolah Menengah Kejuruan (SMK) menjadi kurang cekatan dalam menuangkan idenya, oleh sebab itu menyebabkan pembelajaran yang mereka rasa membosankan. Siswa yang menghadapi kebosanan dalam belajar akan mendapatkan penurunan hasil belajar. Oleh sebab itu, dibutuhkan dorongan yang kuat

Pengaruh Motivasi ...99 
untuk memacu siswa agar selalu semangat dalam belajar hingga bisa mendapatkan prestasi yang gemilang. Semangat belajar dicapai dengan cara meningkatkan motivasi belajar, dari motivasi belajar inilah seseorang siswa mampu untuk berpikir kritis ditengah pandemi Covid-19. Upaya untuk meningkatkan motivasi belajar serta keahlian berpikir kritis telah banyak dilakukan. Motivasi belajar itu sendiri harus dipertahankan keberadaannya serta wajib terus dikembangkan. Berdasarkan uraian tersebut, maka perlu dilakukan sebuah deskripsi untuk mengetahui respon siswa dalam motivasi belajar saat pandemi ini serta seberapa jauh siswa tersebut dapat berpikir kritis ditengah pandemi Covid-19 ini. Penelitian ini bertujuan untuk mendeskripsikan pengaruh antara motivasi dan berpikir kritis dalam pembelajaran online terhadap hasil belajar siswa Sekolah Menengah Kejuruan.

\section{Metode Penelitian}

Penelitian ini dilakukan pada bulan November 2020. Jenis penelitian ini adalah kuantitatif dengan metode analisis yang digunakan dalam penelitian ini adalah Uji t. Terdapat 3 variabel pada penelitian ini yaitu Motivasi (X1) dan Berpikir Kritis (X2) sebagai variable bebas dan hasil belajar $(\mathrm{Y})$ yang merupakan variable terikat. Penelitian ini dilaksanakan di 5 kota yaitu Jakarta, Bandung, Sukabumi, Tanggerang, dan Gunung guruh dengan jurusan yang sama yakni Teknik Konstruksi dan Properti. Dengan sampel 50 siswa. Pada penelitian ini instrumennya dibuat dalam bentuk google form. Instrumen penelitian ini terdiri dari dua bagian yaitu motivasi belajar siswa saat pembelajaran online dan kemampuan berpikir kritis siswa saat pembelajaran online. Instrumen pertama terkait motivasi belajar siswa saat pembelajaran online memiliki opsi jawaban yaitu selalu, sering, kadang-kadang, jarang, tidak pernah.

Seluruh butir instrument terdiri dari pernyataan positif dan negatif. Instrumen kedua terkait berpikir kritis siswa saat pembelajaran online yang memiliki pilihan jawaban yaitu sangat setuju, setuju, ragu ragu, tidak setuju, sangat tidak setuju. Mendeskripsikan berbagai hasil penelitian tersebut dalam bentuk persentase merupakan analisis data yang digunakan dalam penelitian ini. Hasil analisis data terkait dengan motivasi dan berpikir kritis ini dibuat dalam bentuk tabel yang disajikan dalam tabel 1 dan 2 tujuan dibuatkan tabel adalah untuk memudahkan melihat persentase yang terbesar dan terkecil dari jawaban siswa. Teknik analisis data yang dilakukan dalam penelitian ini adalah analisis Regresi Linear Berganda. Regresi Linear Berganda merupakan model regresi berganda yang variabel terikat dan bebasnya berupa numerik. Perhitungan analisis data menggunakan SPSS for windows.

\section{Hasil Penelitian dan Pembahasan}

Hasil dari penelitian ini menunjukkan bahwa secara umum motivasi siswa SMK terbilang tinggi untuk melakukan hal - hal yang berhubungan dengan pembelajaran yang positif. Hasil Penelitian menunjukkan bahwa sebanyak $42.27 \quad \%$ siswa selalu membuat ringkasan ketika selesai pembelajaran yang guru telah jelaskan dengan aplikasi zoom/ google meeet, sedangkan $2.43 \%$ siswa yang tidak pernah membuat ringkasan ketika selesai pembelajaran. Selanjutnya sebanyak $61.9 \%$ menyatakan selalu bertanya lewat whatsapp atau aplikasi lain jika ada pembelajaran yang belum dimengerti, sedangkan $0 \%$ tidak pernah, pernyataan selanjutnya yang memiliki hasil lebih dari $50 \%$ yaitu sebanyak 61.72 persen yang menyatakan selalu menjadi lebih bersemangat jika guru memberikan pujian atas apa yang telah dicapainya, sedangkan $0 \%$ tidak pernah. Ini merupakan implikasi motivasi dalam hal kemandirian belajar saat pembelajaran online, ternyata cukup banyak siswa SMK yang selalu membuat ringkasan ketika selesai pembelajaran yang guru jelaskan, lalu bertanya lewat whatsapp atau aplikasi lainnya jika ada pembeajaran yang masih belum dimengeri serta merasa bersemangat jika guru memberi sanjungan atas prestasi 
yang telah dicapainya Selengkapnya untuk detail data dapat dilihat pada Tabel 1.

Tabel 1. Persentase respon siswa terkait motivasi saat pembelajaran online

\begin{tabular}{|c|c|c|c|c|c|c|}
\hline No & Pernyataan & Selalu & Sering & $\begin{array}{l}\text { Kadang- } \\
\text { kadang }\end{array}$ & Jarang & $\begin{array}{l}\text { Tidak } \\
\text { Pernah }\end{array}$ \\
\hline 1 & $\begin{array}{l}\text { Setelah melakukan pelajaran } \\
\text { dengan Zoom saya akan membuat } \\
\text { ringkasan }\end{array}$ & 42.27 & 19.51 & 34.14 & 4.06 & 2.43 \\
\hline 2 & $\begin{array}{l}\text { Saya bertanya pada guru atau teman } \\
\text { lewat Whatsapp atau aplikasi } \\
\text { lainnya jika ada materi yang tidak } \\
\text { saya mengerti }\end{array}$ & 61.9 & 28.57 & 9.52 & 0.00 & 0.00 \\
\hline 3 & $\begin{array}{l}\text { Saya berinisiatif mengerjakan } \\
\text { latihan soal - soal tanpa disuruh } \\
\text { guru }\end{array}$ & 19.04 & 34.28 & 36.19 & 10.47 & 2.85 \\
\hline 4 & $\begin{array}{l}\text { Saya menjadi lebih bersemangat } \\
\text { dalam belajar saat guru } \\
\text { memberikan pujian atas usaha saya } \\
\text { dalam menyelesaikan suatu } \\
\text { pekerjaan }\end{array}$ & 61.72 & 25.92 & 11.11 & 1.23 & 0.00 \\
\hline 5 & $\begin{array}{l}\text { Saya lebih banyak membuka } \\
\text { entertain (seperti film, podcast, game) } \\
\text { dalam Youtube maupun aplikasi lain } \\
\text { dari pada yang berhubungan } \\
\text { dengan pengetahuan }\end{array}$ & 0.00 & 6.83 & 34.18 & 38.46 & 20.51 \\
\hline
\end{tabular}

Selanjutnya data yang disajikan pada tabel 2 terkait dengan berpikir kritis siswa SMK saat pembelajaran online.

Tabel 2. Persentase respon siswa terkait berpikir kritis saat pembelajaran online 


\begin{tabular}{|c|c|c|c|c|c|c|}
\hline No & Pernyataan & $\begin{array}{l}\text { Sangat } \\
\text { setuju }\end{array}$ & Setuju & $\begin{array}{c}\text { Ragu- } \\
\text { ragu }\end{array}$ & $\begin{array}{l}\text { Tidak } \\
\text { Setuju }\end{array}$ & $\begin{array}{l}\text { Sangat } \\
\text { Tidak } \\
\text { Setuju }\end{array}$ \\
\hline 1 & $\begin{array}{l}\text { Dengan pendekatan sains dan } \\
\text { teknologi saya dapat } \\
\text { memberikan penjelasan } \\
\text { mengenai cara menggambar } \\
\text { sebuah jalan dan jembatan / } \\
\text { gambar teknik/ aplikasi } \\
\text { perangkat lunak dan } \\
\text { perancangan interior gedung } \\
\text { yang kreatif }\end{array}$ & 45.85 & 40.12 & 14.03 & 0.00 & 0.00 \\
\hline 2 & $\begin{array}{l}\text { Pendekatan sains dan } \\
\text { teknologi melatih saya untuk } \\
\text { dapat menjawab pertanyaan } \\
\text { yang dibahas dalam soal - soal } \\
\text { konstruksi jalan dan jembatan } \\
\text { gambar teknik/ aplikasi } \\
\text { perangkat lunak dan } \\
\text { perancangan interior gedung }\end{array}$ & 23.84 & 65.56 & 10.59 & 0.00 & 0.00 \\
\hline
\end{tabular}

Hasil menunjukkan bahwa 45.85\% siswa sangat setuju dengan pendekatan sains dan teknologi yang digunakan dalam pembelajaran mata pelajaran produktif dan sebanyak $14.03 \%$ menyatakan ragu-ragu dalam pendekatan sains dan teknologi yang erat kaitannya dengan pembelajaran kejuruan atau produktif, serta $0 \%$ yang menjawab Sangat tidak setuju. Sedangkan sebanyak $65.56 \%$ siswa merasa dengan pendekatan sains dan teknologi dapat membantu menjawab pertanyaan pertanyaan yang dibahas dalam mata pelajaran produktif.

Tabel 3. Hasil uji t motivasi, berpikir kritis, dan hasil belajar

\begin{tabular}{|c|c|c|c|c|}
\hline No & $\begin{array}{l}\text { Aspek } \\
\text { yang } \\
\text { dikaji }\end{array}$ & $\begin{array}{l}\text { t- } \\
\text { hitung }\end{array}$ & $\begin{array}{l}\mathrm{t}- \\
\text { tabel }\end{array}$ & Keterangan \\
\hline 1 & Motivasi & 1.030 & 2.029 & $\begin{array}{l}\text { Berbeda } \\
\text { signifikan }\end{array}$ \\
\hline 2 & $\begin{array}{l}\text { Berpikir } \\
\text { Kritis }\end{array}$ & 0.743 & 2.029 & $\begin{array}{l}\text { Berbeda } \\
\text { signifikan }\end{array}$ \\
\hline 3 & Hasil & 0.551 & 2.840 & Berbeda \\
\hline
\end{tabular}

102 - Volume 10, Nomor 2, Mei 2021
Belajar

signifikan

Tabel 3 diatas menunjukkan bahwa berdasarkan hasil penelitian dengan hasil analisis regresi berganda dengan SPSS menunjukkan bahwa nilai sig. untuk motivasi mempengaruhi terhadap hasil belajar adalah sebesar $0,308>0,05$ dan nilai $\mathrm{t}$ hitung $1,030<\mathrm{t}$ tabel 2,029, sehingga dapat disimpulkan bahwa tidak terdapat pengaruh motivasi terhadap hasil belajar. Selanjutnya untuk pengaruh berpikir kritis terhadap hasil belajar adalah sebesar 0,461> 0,05 dan nilai t hitung 0,743< t tabel 2,0290 sehingga dapat disimpulkan bahwa tidak terdapat pengaruh berpikir kritis terhadap hasil belajar. Selanjutnya nilai signifikansi motivasi dan berpikir kritis terhadap hasil belajar adalah sebesar $0,580>0,05$ dan nilai F hitung $0,551<\mathrm{F}$ tabel 2,84 sehingga dapat disimpulkan bahwa tidak terdapat pengaruh motivasi dan berpikir kritis terhadap hasil belajar. Dari hasil analisis data menggunakan SPSS di atas menyatakan bahwa, tidak ada pengaruh yang signifikan 
variabel motivasi terhadap hasil belajar mata pelajaran produktif siswa SMK.

Hasil penelitian ini memiliki kesamaan oleh penelitian sebelumnya yang dilakukan oleh (Dinar Tiara Nadip Putri Gatot Isnani, 2015) Secara deskriptif menyatakan bahwa hubungan antara motivasi dan berpikir kritis terhadap hasil belajar menunjukan berbeda signifikan. Banyak hal yang mempengaruhi mengapa hasil yang diperoleh dari perhitungan tidak signifikan antara motivasi dan berpikir kritis ini diantaranya belum optimalnya penggunaan aplikasi dan media pembelajaran yang tersedia karena keterbatasan kemampuan guru yang harusnya peka terhadap teknologi. Serta dikarenakan sulitnya pembelajaran praktikum dilakukan saat pembelajaran secara online, belum maksimalnya inovasi pembelajaran yang dilakukan guru. Selain itu penyebab hasil tidak signifikansi juga dikarenakan jumlah sampel siswa yang sedikit yang dapat mempengaruhi hasil perhitungan tersebut, serta kesalahan waktu dalam pembuatan instrument. Oleh karena itu motivasi belajar dan berpikir kritis yang terbentuk belum berpengaruh signifikan pada peningkatan hasil belajar siswa SMK.

\section{Simpulan dan Saran}

\section{Simpulan}

Berdasarkan hasil penelitian dan pembahasan yang telah dilakukan dapat disimpulkan bahwa hubungan Motivasi terhadap hasil belajar siswa SMK di beberapa kota di Indonesia ini mendapatkan skor yang lebih besar sebagaimana nilai signifikansinya 0.305 lebih besar dibandingkan dengan 0.005 . Serta hasil Uji t-hitung sebesar 1.030. Dari hasil tersebut maka dapat disimimpulkan bahwatidak ada pengaruh yang signifikan antara motivasi terhadap hasil belajar; tidak ada pengaruh yang signifikan antara berpikir kritis terhadap hasil belajar.

\section{Saran}

Hasil penelitian terkait pengaruh motivasi, berpikir kritis terhadap hasil belajar siswa SMK adalah kurangnya pengawasan pembelajaran saat dirumah masing-masing. Sebaiknya orang tua memperhatikan anaknya ketika pembelajaran online di rumah. Lalu saran bagi siswa SMK dan guru untuk tetap menjalankan pembelajaran online ini dengan penuh tanggung jawab. Selain itu, khususnya Bagi guru SMK hendaknya menjelaskan hal-hal yang menarik dan berguna bagi kehidupan siswa yang mengaitkan dengan bahan ajar yang sedang dipelajari sehingga dapat mengoptimalkan hasil belajar siswa. Khususnya Bagi siswa diharapkan agar lebih aktif bertanya ketika pembelajaran berlangsung dan mengerjakan latihan meskipun tidak akan ditunjuk oleh guru sehingga hasil belajar akan lebih optimal lalu meningkatkan motivasi serta berpikir kritis dalam memecahkan soal karena nantinya siswa SMK akan terjun ke dunia usaha dan dunia industri dimana kedua hal ini sangat dibutuhkan; bagi orang tua hendaknya memberikan bimbingan ketika anak mengalami kesulitan dalam belajar dan memberikan dorongan kepada anak untuk lebih giat belajar. Orang tua harus mengontrol kegiatan belajar anak agar hasil belajar menjadi optimal. Yang gunanya dapat membantu siswa untuk berkompeten di bidangnya.

\section{Daftar Pustaka}

Alhawiti, M. M., \& Abdelhamid, Y. (2017). A Personalized e-Learning Framework. Journal of Education and E-

Pengaruh Motivasi ...- 103 Novyanti, dkk. 
Learning Research, 4(1), 15-21. https://doi.org/10.20448/journal.509. 2017.41.15.21

Anggrawan, A. (2019). Analisis Deskriptif Hasil Belajar Pembelajaran Tatap Muka dan Pembelajaran Online Menurut Gaya Belajar Mahasiswa. MATRIK: Jurnal Manajemen, Teknik Informatika Dan Rekayasa Komputer, 18(2), 339-346. https://doi.org/10.30812/matrik.v18i 2.411

Averkieva, L., Chayka, Y., \& Glushkov, S. (2015). Web Quest as a Tool for Increasing Students' Motivation and Critical Thinking Development. Procedia - Social and Behavioral Sciences, 206(November), 137-140. https://doi.org/10.1016/j.sbspro.2015 .10 .042

Cahyani, A., Listiana, I. D., \& Larasati, S. P. D. (2020). Motivasi Belajar Siswa SMA pada Pembelajaran Daring di Masa Pandemi Covid-19. IQ (Ilmu AlQur'an): Jurnal Pendidikan Islam, 3(01), 123-140. https://doi.org/10.37542/iq.v3i01.57

Dinar Tiara Nadip Putri Gatot Isnani. (2015). Pengaruh Minat Dan Motivasi Terhadap Hasil Belajar Pada Mata Pelajaran Pengantar Administrasi Perkantoran Dinar. Jurnal Pendidikan Bisnis Dan Manajemen, 1(5), 118-124.

Fauci, A. S., Lane, H. C., \& Redfield, R. R. (2020). Covid-19-navigating the uncharted. Mass Medical Soc.

Hakim, A. (2010). Model Pengembangan Kewirausahaan Sekolah Menengah Kejuruan ( Smk ) Dalam Menciptakan Kemandirian Sekolah. Riptek, 4(1), 114.

Hanum, N. S. (2013). Keefetifan e-learning sebagai media pembelajaran (studi evaluasi model pembelajaran elearning SMK Telkom Sandhy Putra Purwokerto). Jurnal Pendidikan Vokasi, 3(1), 90-102. https://doi.org/10.21831/jpv.v3i1.15 84
Harasym, P. H., Tsai, T. C., \& Hemmati, P. (2008). Current trends in developing medical students' critical thinking abilities. Kaobsiung Journal of Medical Sciences, 24(7), 341-355. https://doi.org/10.1016/S1607551X $(08) 70131-1$

Ibda, H. (2018). Penguatan Literasi Baru Pada Guru Madrasah Ibtidaiyah Dalam Menjawab Tantangan Era Revolusi Industri 4.0. Journal of Research and Thought on Islamic Education JRTIE), 1(1), 1-21. https://doi.org/10.24260/jrtie.v1i1.10 64

Ichsan, I. Z., Rahmayanti, H., Purwanto, A., Sigit, D. V., Kurniawan, E., Dewi, A. K., Wirdianti, N., Hermawati, F. M., \& Marhento, G. (2020). PEMBELAJARAN SAINS DAN LINGKUNGAN DI SMP yang berisi himbauan kepada masyarakat untuk melakukan Physical Distancing menjaga. E- Journal UMM, 6, 50-61.

Ku, K. Y. L., Kong, Q., Song, Y., Deng, L., Kang, Y., \& Hu, A. (2019). What predicts adolescents' critical thinking about real-life news? The roles of social media news consumption and news media literacy. Thinking Skills and Creativity, 33(May), 100570. https://doi.org/10.1016/j.tsc.2019.05. 004

Kumar, V., \& Nanda, P. (2019). Social media in higher education: A framework for continuous engagement. International Journal of Information and Communication Technology Education, 15(1), 109-120. https://doi.org/10.4018/IJICTE.2019 010108

Malekian, F., Akhtar, M., \& kakabaraee, K. (2013). Designing Training Math in Fifth Grade (Based on Logical Approach) and the Role of It on Critical Thoughts, Behaviour and Students Academic Motivation. Procedia - Social and Behavioral Sciences, 82

790-795. 
https://doi.org/10.1016/j.sbspro.2013 .06 .350

Nursalam, 2016, metode penelitian, \& Fallis, A. . (2013). Efektivitas Metode Pembelajaran Daring Terhadap Motivasi Belajar Mahasiswa Saat Pandemi Covid 19 Di Kota Pekanbaru Nia. Journal of Chemical Information and Modeling, 53(9), 1689-1699.

Polat, Ö., \& Aydın, E. (2020). The effect of mind mapping on young children's critical thinking skills. Thinking Skills and Creativity, 38 . https://doi.org/10.1016/j.tsc.2020.10 0743

Pujiasih, E. (2020). Membangun Generasi Emas Dengan Variasi Pembelajaran Online Di Masa Pandemi Covid-19. Ideguru: Jurnal Karya Imiah Guru, 5(1), 42-48.

https://doi.org/10.51169/ideguru.v5i 1.136

Quinn, S., Hogan, M., Dwyer, C., Finn, P., \& Fogarty, E. (2020). Development and Validation of the StudentEducator Negotiated Critical Thinking Dispositions Scale (SENCTDS). Thinking Skills and Creativity, 38(August), 100710. https://doi.org/10.1016/j.tsc.2020.10 0710

Sadikin, A., \& Hamidah, A. (2020). Pembelajaran Daring di Tengah Wabah Covid-19. Biodik, 6(2), 109119.

https://doi.org/10.22437/bio.v6i2.97 59

Seibert, S. A. (2020). Problem-based learning: A strategy to foster generation Z's critical thinking and perseverance. Teaching and Learning in Nursing, 16(1), 85-88. https://doi.org/10.1016/j.teln.2020.09 .002

Sjukur, S. B. (2013). Pengaruh blended learning terhadap motivasi belajar dan hasil belajar siswa di tingkat SMK. Jurnal Pendidikan Vokasi, 2(3), 368-378. https://doi.org/10.21831/jpv.v2i3.10 43

Syah, R. H. (2020). Dampak Covid-19 pada Pendidikan di Indonesia: Sekolah, Keterampilan, dan Proses Pembelajaran. SALAM: Jurnal Sosial Dan Budaya Syar-I, 7(5), 395-402. https://doi.org/10.15408/sjsbs.v7i5.1 5314

Umairah, P. (2020). Peningkatan Motivasi Belajar Menggunakan " Google Classroom " Ditengah Pandemi Covid-19 Pada Peserta Didik Kelas Xi Ips 4 Sman 1 Bangkinang Kota. Journal On Education, 02(03), 275-285. http://www.jonedu.org/index.php/jo e/article/view/319/250

Wibowo, N. (2016). Upaya Memperkecil Kesenjangan Kompetensi Lulusan Sekolah Menengah Kejuruan dengan Tuntutan Dunia Industri. Jurnal Pendidikan Teknologi Dan Kejuruan, 23(1), 45. https://doi.org/10.21831/jptk.v23i1.9 354 